\title{
TRANSFORMATION MODELS OF UNUSED SPATIAL RESOURCES \\ Research Study of Cultural Center "Magacin" in Belgrade
}

\section{A B S S T R A C}

This paper researches different transformation models of unused spatial resources in order to recognize aspects which could lead towards a sustainable activation of space. The relevance of the research lies in both scientific interpretations, and the clarification of the transformation phenomenon relating to the activation of unused spatial resources, especially in the context of post-socialist Serbia with a focus on its capital. The theoretical framework of the research relates to different aspects of urban sustainability regarding the activation of unused spatial resources, including further clarification of the role of the transformation principles in architectural discourse. The empirical part of the research regards a case study analysis of the precise spatial framework of "Magacin" Cultural Center in Belgrade using a student involved workshop as a research method. The students were expected to explore different possibilities and propose design solutions for the given space applying a transformation method in the context of space activation. The final part of the research includes the synthesis and the result interpretation regarding the research context and the problem setting, but more importantly, it demonstrates the level of interdependency between changes on micro-level (transformation models of unused spatial resources) and the context of macro-level (activating space in terms of sustainable urban development).

Ksenija Pantović

University of Belgrade - Faculty of Architecture

Iva Čukić

Ministry of Space, Belgrade
KEY WORDS

TRANSFORMATION MODELS

TRANSFORMATION PRINCIPLES

UNUSED SPATIAL RESOURCES

URBAN SUSTAINABILITY

CULTURAL CENTER "MAGACIN"

STUDENT WORKSHOP 


\section{INTRODUCTION}

The fluid context in which contemporary architecture occurs is entirely defined by the paradigm shift, which is manifested through the divergence of all aspects of a contemporary society, migration, volatile social and economic conditions, negative effects of climate change and globalization, rapid technological development, as well as the diversity of cultural discourse and users' quotidian needs. ${ }^{1}$ The decrement of an average building life cycle, as well as the necessity for adaptive reuse, is one of the effects of the aforementioned processes indicated by contemporary research. As a result, contemporary cities should aim to gradually increase capacities for changes in order to handle future demands. ${ }^{2}$ However, due to constant and rapid urban sprawl over the past decades, restrictions of the sprawl are being proposed, as well as the introduction of an approach through which the principles of the compact city would be achieved. Therefore, in order to avoid negative effects of an urban sprawl, the essential component in the creation of an "intelligent, sustainable and social city model" is precisely the activation of spatial resources which are no longer being used or which are abandoned. ${ }^{3}$

Over the last decades of the past century, alterations in the economic structure have occurred, increasingly transforming into financial and trading centers, ${ }^{4}$ while the transition to the market economy made direct spatial impacts on the urban tissue. One of the most apparent impacts refers to a great amount of unused, typologically diverse, spatial resources, that can no longer meet the requirements of the functions they were initially designed for. In the context of pursuing sustainable solutions, different forms of reconstruction, revitalization, or adaptive reuse are being imposed. In Europe, this kind of heritage has a great potential regarding the improvement of different efforts to create a sustainable and humane environment. ${ }^{5}$ In a local context, however, unused and abandoned spaces are a consequence of transformation processes and transition from the economic system to the market economy which was initiated in Serbia in 2000, after the period of socialism, and which made significant spatial imprints in the urban setting. Namely, a combination of transition processes, transformation longevity, thus privatization, i.e. the rapid process of the decrement of social and national assets, as well as the inauguration of foreign capital investment, has affected urbanization process in terms of elements of spatial structure, as well as employing spatial resources. ${ }^{6}$ Leading processes of demilitarization and deindustrialization have left significantly conspicuous imprints in the urban tissue, and, many other assets have also lost their original function. Research that has been previously undertaken regarding the activation of inactive spatial resources has been concerned with creating conditions for local economic development by effectively using development land. ${ }^{7}$ 
In the given context, and simultaneously with the aforementioned rapid changes, one of the self-imposed necessities is the activation of unused or abandoned spatial resources. The absence of an adequate methodological approach to the process of transformation of these spaces is especially evident in the countries with transition economy, which mostly aspire to short-term objectives and respond primarily to private investors' interests. ${ }^{8}$ The transition period in Serbia, the country with evident socialist heritage, demands the adjustment and transformation of numerous unused and vacant spaces in order to formulate methods and processes which could lead to their eventual reactivation. Since architecture as a discipline aspires to adaptation and problem resolution, gradual advancement of various contemporary design methodologies is being imposed exactly by positioning and applying transformation principles in both theory and practice of an architectural design. ${ }^{9}$ Also, in the process of adjusting architectural ideas to a multicultural and volatile context, requirements for a flexible, adaptive, mobile, or interactive environment emerge. Therefore, diverse transformation models are evolving in order to activate the existing, but still insufficiently employed spatial resources. In this regard, one of the aims of this research concerning the potential and effects of transformation principles on the process will further be discussed. By identifying different transformation models, the objective is to simultaneously expand the sphere of possibilities for creative actions in architectural and urban design. Furthermore, the intention is to indicate that by introducing specific design methodologies in the process of activating spatial resources, the implementation of sustainable solutions can be affected as well. In regard to this matter, Nikezić and Marković argue how specific 'place-based' education of architects can affect sustainable awareness and generate specific design framework which has both environmental and cultural implications. ${ }^{10}$ Through this approach, not only are new design methodologies being developed, but architects are also becoming the advocates of the process of creating a sustainable environment.

As an initial issue of the research, the position of transformation phenomenon as the design model emerges, which was previously insufficiently examined in terms of activating unused spaces. In other words, the question arises: how are current spatial resources adapting to the volatile context? Therefore, this research paper argues that by activating unused spatial resources, different aspects of sustainable urban development are being endorsed. This thesis regards processes which contribute to the long-term functioning of the city, especially in the setting of post-socialist countries. However, the possibilities of activating unused spaces will be observed through the specter of transformation phenomenon, thus based on this, we can argue that application of transformation models is becoming an integral part of methodological apparatus in the context of activating unused spatial resources. 
The concluding part of the paper includes the synthesis and interpretation of the results, based on the initial setting of the problem, by defining different models of transformation. The resulting analysis of the research process focuses on recognizing various methods and apparatuses which assist in achieving transformation in a certain space. The results demonstrate the level of interdependence between changes on micro-level (transformation models of unused spatial resources) and the context of macro-level (activating spaces in terms of sustainable urban development).

\section{METHODOLOGICAL APPROACH}

The research required applying several scientific methods from the domain of architectural and urban studies, from which we can distinguish two levels of research, theoretical and empirical. In the first segment of the research, by analyzing the content of extensive literature, which involves creating a basis for data in order to understand the term of transformation more closely, regarding the activation of unused spatial resources. Through an interpretive analysis of bibliography from the domain of architectural and urban studies, the main theoretical concept was established as a framework for understanding the role of transformation models in the contemporary context of activating unused spatial resources. Based on theoretical settings, which are used to inquire the phenomenon of transformation in terms of activating unused spatial resources in the context of urban sustainability, the particularities of this approach will be examined together with their interdependence.

The empirical part of research regards to the operative analysis of the "Magacin" Cultural Center case study as a part of architecture student workshop which was used as a methodical model for experimental research in real-time conditions. The objective of the workshop was creating a basis consisting of various sustainable solutions which could be applied in the given space. Through theoretical and practical work, students demonstrate unique design, architectural, and methodological principles for activating the space situated in the center of Belgrade. Other than collecting the data on the site, the workshop also included the analysis of primary documents, which relate to the examined urban space, but also the systematization of data collected from social networks, as well as the interviews of space users.

The workshop aftermath included the evaluation and interpretation of the results by using a comparative analysis of students' proposals based on the previously defined criteria of transformation. One of the expected results is presenting the entire assortment of transformation models which can be applied in the process 
of activating unused spatial resources if we observe the micro-level, as well as their influence on issues regarding urban sustainability in the terms of macrolevel. Furthermore, through the synthesis and interpretation of results, aspects which lead the towards sustainable use of space will be highlighted.

\section{THEORETICAL FRAMEWORK}

\section{Activation of Unused Spatial Resources}

If we perceive architecture as a personification and reflection of the society and a contemporary context, in a specific moment in time, the continuous idea of change can be singled out as the only invariable. The divergent context in which contemporary cities are being developed, primarily defined by rapid development, generates contemporary cities as flexible, fluid, amorphous, and hybrid creations where the duration is defined by the velocity of change. ${ }^{11}$ Over the past few decades, various concepts of sustainable development are being imposed as a global approach to the development and adjustment to alterations. The issue of unused or abandoned spatial resources, in the context defined by rapid changes, is especially up-to-date since it clearly illustrates the problem of adapting architecture to the users' new necessities, as well as a volatile context.

Influenced by the economic crisis and as a result of political and economic instability in Serbia, a gradual increase of spaces that are built, but still unused can be perceived. Previous research in Serbia mainly focused on possibilities and risks of adaptive reuse of industrial and military complexes and buildings, but also on less complex types of utility buildings, such as abandoned hospitals, schools, cultural centers, etc. ${ }^{12}$ Reasons why unused or decay vacant buildings and locations should be activated relate to mainly devastating economic, ecological, and environmental effects among which the crucial ones are: (1) depreciation of economic value of land in the area where this kind of locations is situated; (2) lost economic effects of the location; (3) encouraging increase of social pathologies (criminal, prostitution, drug abuse, etc.); (4) the origin of possible contaminations; (5) the result of numerous ecological noxae (odor; endangered ecological system, etc.); (6) a psychological effect on neighbouring residents; and (7) a jeopardized identity of the part of the city or city itself. ${ }^{13}$

The issue of activating unused spatial resources became partially employed only in the late 2000s mainly in the documents relating to strategic management and planning. In these documents, the elements of European planning practice can be recognized, such as "territorial capital", "sustainable spatial development", "spatial integration", "functional urban areas", etc. ${ }^{14}$ However, certain domestic authors consider that strategic documents are saturated with 
optimism which contradicts the actual reality in Serbia and that prior agenda of urban development deteriorates, i.e. Serbia, regardless of declaring numerous development documents, has no adequate strategies fundamental for the course of sustainable urban development. ${ }^{15}$ Furthermore, according to the aforementioned documents, the way in which this problem can be considered, relates to concepts of sustainability, sustainable development, sustainable city, etc., in other words, they are parts of various domains which are defined by sustainability anchors. Nevertheless, it is necessary to highlight how numerous incoherent definitions differently and inaccurately interpret the paradigm of sustainable development, which is also related to theoretical and scientific interpretations of these concepts. These additional ambiguities are partially caused by certain aspects and components of sustainability which regard different dimensions of development. However, contemporary tendencies in urban planning are considered as a part of global trends which claim that planning operates according to principles of the free market, ${ }^{16}$ while the concept of sustainable development is comprehended as a counterbalance to economic liberalization. ${ }^{17}$ Some authors, however, believe that the concept of sustainable development is being often used mainly as a phrase, i.e. without a clear understanding of its effect on urban development, ${ }^{18}$ underestimating the influence that these concepts could eventually have in the context of planning agenda and innovative solutions for urban development. Even if the sustainable development was comprehended as a general global development model related to almost all segments of human life, it would still not offer accurate directions of further development. ${ }^{19}$

In this context, the future of architecture practice is still anticipated according to economic interests, while the position toward environment and community depends on personal affinities and individuals' responsibility. However, contemporary dynamics of the city development requires integrating sustainability principles in the design process, with special regard to recycling of the space by applying contemporary methodological actions for adaptive reuse of unused or abandoned spaces. This includes constant recalling of sustainability concept which requires the redefinition of design methods, as well as the redefinition of an approach to contemporary architecture practice which requires establishing itself according to the sustainability principles. A sustainable approach to architectural design and development of the cities can be traced in the complete evolution of architecture and urbanism. Also, the essence of the sustainability concept lies in understanding and consequently designing according to human necessities and aspirations, ${ }^{20}$ which precisely encourages architecture practice to evolve in an innovative and responsible manner with the potential of adapting in accordance with sustainability objectives. 
When it comes to sustainable urban development, it is necessary to aim to create a city and space, suitable for users as a dwelling space and with an adequate number of resources, not only considering the form and energy efficiency, but also considering its function. ${ }^{21}$ As a result of not being concluded, nor hermetic, but on the contrary, quite dynamic, the characteristics of the concept of sustainable urban development could potentially be adjusted to different social, political, and historical contexts. ${ }^{22}$ With regard to transformative potential, urbanistic and architectural practices can be altered seeking innovative solutions which could consequently lead to sustainable agendas in a broader sense. In this context, the orientation towards the existing, underused areas (buildings and their surrounding land), is crucial for improving the environment and for the sustainable development of the cities..$^{23}$

\section{Transformation Principles in the Context of Activation of Unused Spatial Resources}

With regard to the hypotheses, which were previously introduced and which indicate the potential for activating unused spatial resources more sustainably, it is necessary to define certain design mechanisms in order to further define the theoretical framework of this research. Inactivity of spatial resources is a specific feature which can relate to various typologies, therefore it is necessary to observe this specific design issue in a broader architectural discourse.

If we examine the meaning of the term 'transformation' more thoroughly, we can observe that it is defined through the idea of a change as a continuous process, or more specifically through the idea of metamorphosis or alteration of the existing, which enables transformation principles to be considered as a complex mechanism, i.e. methodological apparatus which simultaneously advocates different dynamic principles that carry the potential of change. If we further analyze the conceptual framework defined by transformation, regarding relevance and the amount of use, we can elicit the following dynamic principles: mobility, ephemerality, modularity, prefabrication, perceptive transformation, universality, open plan, interaction, and improvisation. ${ }^{24}$ The listed classification of transformation principles should serve as an indicator for further examination and analysis of the specific application of these principles in the process of activating unused spatial resources in the contemporary context. Regarding the particularity of this research, which is defined by the concept of sustainability, the dominant principles are listed: mobility, ephemerality, modularity, prefabrication, free plan, interaction, and improvisation. Their way of application and relevance for the research will subsequently be precisely described in the following paragraphs. 
Architecture as a discipline longs for adaptation which is demonstrated through the development of different strategies which could have the ability to adjust swiftly. The evolvement of dynamic concepts in architectural discourse was initially introduced in manifesto, ideology, and works of avant-garde groups which designed in the early years of the 20th century. In this context, traditions of futurist movement, which appeared in Italy in the 1920s and demonstrated mobility principles, significantly emerge..$^{25}$ The mobility principle advances parallel with the advance of technology and quickly becomes the main characteristic of the cities of the 20th century. Initially, the mobility principle related to the term of motion, but also to mechanization of the entire society. Within the architectural discourse different practice of this principle appears, and it is commonly associated with the category of mobile architecture. Codrescu defines mobile architecture as the branch of architecture which represents physical motion, the one that changes its place in a certain unit of time. ${ }^{26} \mathrm{~A}$ typical feature of this category is the transformation of urban surroundings as a result of movability and adaptation to different conditions of the given context. Therefore, according to this definition, we can presume that applying this principle can also relate to various types of interventions in space which have the ability of motion.

In the second half of 20th century, theories, that offer new interpretations of concepts of mobility related to flexible architectural conceptions, emerge. ArchitectYona Friedman in his manifesto "Mobile architecture" interprets mobile architecture as the one that is based on flexibility, or in other words, limitless possibilities for a user to define the structure entirely according to his needs. ${ }^{27}$ Friedman's concept of mobility is closely related to Nieuwenhuys' project New Babylon in terms of an idea of free movement. In New Babylon, this principle is indicated in the context of infinite freedom of users to undisturbedly move in order to meet their specific needs. ${ }^{28}$ Based on these assumptions, the ideas about open systems appear, which are able to transform themselves according to users' changeable needs. The idea of a city which would be able to reconfigure and transform itself represents a radical concept which is demonstrated in almost all projects by Archigram such as "Walking city" from 1963, or "Instant city from 1968. The rapid progress of the digital paradigm from the end of the 20th century, generates new models of mobility, by interpreting different ways of motion which affect the genesis of fluid architectural conceptions.

Relevant theoretical backgrounds of transformation principles also relate to the advance of various ephemeral structures in architectural discourse. Depending on the type of need and the durability of the structure, by applying the principle 
of ephemerality, various typologies are being generated: art installations, assembly platforms, pavilions, temporary housing, etc. A common denominator for all ephemeral structures is a limited time period in which a certain function has been actualized. ${ }^{29}$ Some of the main aspects of these structures regard to flexibility, diversity of functions, the possibility for physical transformations, as well as the potential for recycling, and consequent reuse. The rapid emergence of the digital paradigm during the 90s has significantly influenced changing of perception of space in term of questioning the idea of time. Along with the advance of technology, experimental models appear in order to create cities that would respond to the users' needs as well as the needs of the new era. New information age generates fluid and flexible buildings with ephemeral aspects. ${ }^{30}$ Zygmunt Bauman, on the other hand, discusses the term of ephemerality in the context of a contemporary city which is defined by fluidity and unambiguous logic of a constant progress while perpetually seeking for the new identity. In this sense, performing ephemerally in the built context is distinguished as a method for solving the prevailing problem, but it can also simultaneously represent the renouncement of the mistake which can be caused by performing permanently. The result, which is by any means ephemeral, is the fact that identity only becomes set or appointed with an indefinably short life-cycle. ${ }^{31}$

Further, the rapid advance of technology initiated the processes of industrialization as well, whose results in the architectural discourse reflect through several phenomena and concepts like new construction systems, mass production, modularization or prefabrication system. It started offering a spectrum of possibilities for the formation of the architectural oeuvre. Universalization of architectural components, other than efficiency and the satisfactory economic result, also offers a creative base for architects in the process of creating new design conceptions. Thus, introducing the principle of modularity and prefabrication system generates a very rational framework for the design process, which enables the decrease of complexity and influences the flexibility of constructing. Since the role of modularization is mediating between the conflict demands for mass production, on one hand, and diversity, ${ }^{32}$ on the other, the relevance of this approach can be perceived in the fact that by combining a limited number of factory produced modules, both form and structure can be transformed in order to produce large amount of different solutions according to specific users' preferences.

With regards to this, the introduction of structural grid system is distinguished, as it enables numerous flexible spatial conceptions which could adapt to users' needs. At the beginning of the 20th century, Le Corbusier introduced "the Five 
Points of a New Architecture", among which is also the point of "free plan". By separating facade from the structure, the free plan principle enables the transformative potential of flexible spatial configurations which can be adapted according to necessities. Furthermore, along with the structural logic of the structural grid system, the ideas of the universality of space are being developed through the possibility of the level of meeting people's needs, multivalence of space, and an open approach to design. ${ }^{33}$ Having in mind the continuous advance of flexible conception based on the principle of openness, the free plan can also be interpreted as an open plan.

Bernard Leupen identifies 3 dimensions through which buildings can express their openness: the ability to change, the ability to expand, and polyvalence. ${ }^{34}$ The ability to change includes the existence of at least one level in space that is entirely transformable (e.g. mobile partitions, walls, and so on). The ability to expand includes spaces whose boundaries are not firmly defined, but which can variate. In polyvalent spaces, different functions occur, and these spaces can be used in different ways without any need for architectural or structural modification. ${ }^{35}$

In the context of activating abandoned spatial resources, it is necessary to distinguish polyvalence as one of the significant characteristics, since it implies the possibility of transformation through the application of different programs inside the existing framework. The permanence of the solution is resolved with infinite possibilities of transforming the plan which can accept a variety of different functions. Thesis about the event, which becomes essential in generating architecture, is also present in the essays by Bernard Tschumi in which the theories of understanding the space are being expanded. By introducing the issue of the event in architecture, Tschumi recalls Situationist theories from the 60s, which promote the idea of the architecture of event. One of the main theseis, which Tschumi advocates, is that there is no architecture without the event and the agenda, that is to say, architecture is never just a form, but also an affirmation of its function, which involves the social and political plan, as well. ${ }^{36}$ The flexibility of this approach can also be noticed in the doctrine of liberating spatial conception from only one meaning of the term individual as it continuously offers possibilities to develop new identities. In the end of the 20th century, in the context of the rapid advance of different globalization processes, multivalence of architectural conceptions starts to be related to the process of hybridization. Hybridization arises as the process in which multiple identities are being merged in one ineffable, undefined identity, something like software that is being perpetually coded using new coding languages every time. 
Hybrid identities, produced by architecture, establish themselves in all levels of comprehension of the architectural oeuvre, through form, function, materiality, and questions of place. Hybridization represents a dynamic process of activating the structure, it solves the issues of distributing functions, individual purposes, and the urban tissue which surrounds the structure. ${ }^{37}$

Other than openness, which is here interpreted in a specific way, principles corresponding to this approach are interaction and improvisation. In architectural discourse, the interaction principle is identified through the concept of "Wesenhafte Gestalt", which represents a theoretical background for the design in German expressionism. It is a concept which implies that spatial configuration emerges as the result of a process of interaction between the user and space. "Wesenhafte" concerns the person primarily and it initiates that spatial structure - "Gestalt" occurs under the notion of mapping users' behavior which further implies that the final form reflects much more than a merely effective realization of the set functional plan. ${ }^{38}$ Spatial structure is formed as a result of this reaction, thus architectural structures become the reflection of users' simultaneous trajectories. In the context of this research, creating interactive systems is significant because of the possibilities to generate space which can adjust to different changes depending on individual, social, and environmental needs. Additionally, in the concept of interaction between people and architecture, the change of roles between users and participators is very relevant. Different types of interaction can be perceived which influence genesis of the project and relate to the interaction among users, or between the user and the building, or between the building and the surroundings. ${ }^{39}$ The latter advance of digital media perceives its result through introducing intelligent systems which further improve interactivity models.

Promoting the concepts of openness and open (free) plan, within the architectural discourse, implies the possibilities of an infinite number of different interpretations, which also brings the improvisation principle into focus. In the context of research, this principle is very significant since it emphasizes the different unpredictable effects which are caused by users or architects during the design process. The relevant approach in the context of positioning the improvisation in the architectural discourse is promoted by Jencks and Silver through the notion of ad-hocism which is introduced in the architectural criticism in the book carrying the same title in 1972. The term of ad-hocism explains the design approach which effectively and creatively solves problems by using different available resources. This approach promotes the transformation principle through the potential of using recycling and adaptation as a method. Jencks emphasizes the notion of democracy of the design process in the context of personalizing the designed structure. ${ }^{40}$ 
In the previous framework of the research, the importance of applying the transformation principles has been brought to attention, not only in the context of adapting to a variety of changes but also as one of the possible tools for activating unused spatial resources. Throughout the history, and simultaneously with the advance of technology, accordingly with the rapid change of life conditions which resulted with new needs, problems, and requirements, the role of transformation principles, and furthermore transformation models, grows and changes in order to adapt to these changes. With regard to this, the principles, which are being applied within the boundaries of certain existing spatial resources, can further be examined.

\section{CULTURAL CENTER “MAGACIN" - RESEARCH STUDY}

In Serbia, almost every city or municipality possesses a significant number of unused and abandoned spaces, whose primary function is no longer considered as sustainable. The reason for that is usually inadequate space capacity, or lack of interest on the market, even the absence of adequate planning agendas which could define conditions and sustainable models of use. ${ }^{41}$ At the same time, these unused or abandoned spaces are increasingly becoming places of interest for the local communities, informal groups, or individuals, which by introducing new activities, define new models of space or function arrangement. Namely, the research "The Map of Action" that was done with an objective to map informal initiatives based on DIY philosophy, which are practicing different ways of activating spatial resources in Serbia, showed that over the last few years the interest of local initiatives for the issue of reuse of unused spaces has increased. ${ }^{42}$ Regardless, the current normative boundary lacks precise mechanisms and tools which would regulate the issue of activating the unused space and assigning it for a temporary use. ${ }^{43}$

The only project which was ambitiously announced as the first alternative cultural center in Belgrade, whose activities would be performed by the association of civil sector (later gathered around "Association Independent Cultural Scene of Serbia" - a joint platform of organizations, initiatives and individuals in the fields of culture and arts in Serbia) with the support from the city, was the warehouse in the street of Kraljević Marko in Savamala. ${ }^{44}$ Namely, the resolution of the city authorities was to grant the formerly abandoned warehouse to the culture-related associations for temporary use. However, the plan was not entirely realized, firstly because of the absence of genuine willingness of the authorities to introduce innovations within the procedures of activating unused spaces, and thus define the new model for similar cases around Belgrade..$^{45}$ Currently, this space works under unregulated legal 
conditions, and users of this space are constantly working on preventing this space from being terminated, as well as finding a new model for it to function. Namely, this rare, but positive example represents a valuable rethinking of cultural production by the local context and an innovative collaborative space. After doing the interviews with the users of this space, it was confirmed that the space of "Magacin" is being used by more than 40 organizations from the sphere of culture. Thanks to the collaborative model of use, space produces over 900 activities per year, three per day averagely, that relate to culture and art, involving exhibitions, educational programs, movie projections and plays, dance and circus performances, including daily preparations for this rich and diverse program.

In order to finally regulate their own status, the users of this space had started to participate in negotiations with the authorities, and the issue of defining space capacity and possibilities for different uses and numerous programs arose. In the attempt to define the problem of the further use of this repository space, but also other unused spaces, a workshop which deals with the transformation of this space was organized, and the results were predicted to be used as an argument in the negotiation process with the authorities. Additionally, after almost 10 years, the users of the space had a need for the specific arrangement of the interior multifunctional space which would respond to different functional and esthetic needs of the users, and which would also provide maximized conditions for comfortable sojourn and efficient work. Because of all the aforementioned reasons, the architecture workshop "What kind of a cultural center do we need? The case of CC "Magacin" was organized.

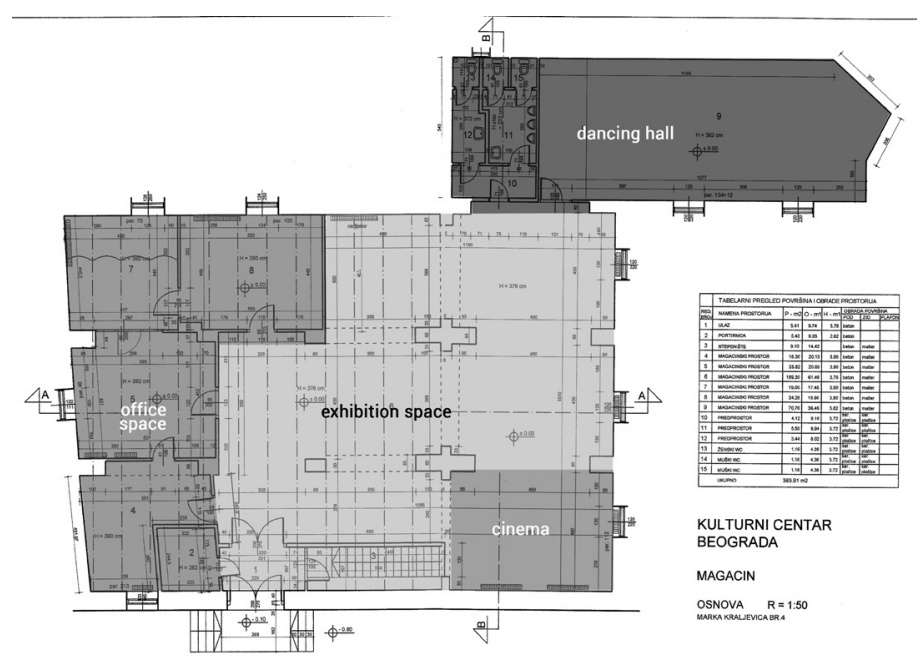


Space, that is $1200 \mathrm{sqm}$ large, includes an office and exhibition space which cannot be used by their full capacity because of the decay, and a complete reconstruction has so far been impossible due to limited financial resources of the users. For this reason, in the three-story building currently only the ground floor is being used which occupies an area of $380 \mathrm{sqm}$ and which consists of (Figure 1) large exhibition space, office space, a cinema and a dancing hall. The building was constructed using the structural grid system with massive concrete columns which intersect the space. The dance hall, which also contains the sanitary block, is entirely isolated from the central zone, and the office space is separated from the central zone with plaster partitions.

\section{Student Workshop as Research Method}

The initial idea of this workshop was for students to, together with the tutors and in teams, explore the skills and methods of arranging the interior multifunctional space by applying different transformation models which could contribute to adaptation of this space which is aimed at diverse cultural and artistic production. It is necessary to emphasize that in the broader sense, the objectives of the workshop were oriented towards introducing various possibilities of transformation which could be used for the process of activating unused spatial resources. In a more narrow sense, the proposed models of the transformation of the space can be interpreted as possible implementational physical interventions regarding the specific space of "Magacin". As a matter of fact, applying and combining different principles of transformation aims to indicate sustainable scenarios for the future functioning of this space.

The two-day workshop consisted of the theoretical and practical part. The theoretical framework of the workshop was initially defined by various discussions and lectures aiming to inform students about the topics relating to the activation of unused spatial resources in the context of urban sustainability. At the same time, the focus was on the investigation of different design techniques by introducing the notion of transformation, flexibility, or adaptation, with the final objective of creating a conceptual framework for functioning which was related to the process of adjusting to changes, but which simultaneously promoted the ideas of sustainable urban development. With regard to the set transformation principles (mobility, ephemerality, modularity, prefabrication, universality, open plan, interaction, and improvisation), the students were assigned with a task of examining or applying these principles in the case of CC "Magacin". The idea was to inquire how these dynamic concepts can be applied inside a certain space with an aim to promote sustainable use. By applying the aforementioned principles specifically, students also rethinking their own 
creative methodologies. Moreover, one of the objectives was to discover new ways of usage and application by eventually integrating the defined principles, or specifically applying them which could further improve the scenarios of use.

\section{Project Task}

In order to actualize the practical part of the workshop, it was necessary to create a project task based on which students could propose particular interventions. In order to define the project task with utter precision, it was necessary to determine the needs and activities of different users, which was achieved by using the method of an interview. During these two days, students had the opportunity to meet the users of the space, as well as their specific needs, and, at the same time, contemplate the issue of arranging this space. This process involved a skilled approach to understanding their needs and an organization of functional units which should eventually provide them with the maximized conditions for comfortable sojourn and efficient work.

After the interviews were finished, the students analyzed predominant activities that require specific spatial framework and conditions each in its own way. Working in teams, the students distinguished dominant activities which occur, and also set the classification based on relevance in order to more accurately meet different requirements. In that context, priority domains were defined, ranked in the following manner: (1) dance performances, (2) art performances, (3) exhibitions, (4) cinema projections, (5) presentations and roundtable discussions, (6) theatre performances, (7) office space. The performed analysis and systematization of activities enabled generating a defined design task, which served as a conceptual framework for specified proposals and interventions within the given space. It is necessary to emphasize that all these activities were considered as dynamic, or volatile. However, even though they were systematized according to current needs and the level of occupation, the rapid dynamics of potential future changes required a certain concept of contemplation which would involve effortless reuse according to the change of relevance of a certain activity. Each of these activities required certain utility rooms (for storing equipment and belongings, as well as dressing space), thus the idea was to treat them potentially as static spatial elements.

\section{The Workshop Results}

Due to the specificity of a given spatial framework, and according to the level of intervention and potential, students divided space into three main zones: office space, central space, and a dance hall. 
Based on the previously analyzed and presented theoretical framework, students attempted to respond to the specificity of a project task. Additionally, after the interviews were completed, which determined the ranking of activities, other spatial interventions were taken into consideration which relate to models of transformation for space. According to the spatial zone of intervention, it is possible to comparatively follow and analyze the results of students' interventions. In the following table, typical interventions and proposals will be shown:

Table 1. Overview of students' interventions concerning the defined spatial zone

\begin{tabular}{|c|c|c|}
\hline $\begin{array}{l}\text { ZONE OF } \\
\text { INTERVENTION }\end{array}$ & $\begin{array}{l}\text { DESCRIPTION OF THE } \\
\text { INTERVENTION }\end{array}$ & $\begin{array}{l}\text { REPRESENTATION OF THE } \\
\text { INTERVENTION }\end{array}$ \\
\hline \multirow{2}{*}{$\begin{array}{l}\text { Central space } \\
\text { Intervention No. } 1\end{array}$} & Curtain Walls & \\
\hline & $\begin{array}{l}\text { In this proposal, students decided } \\
\text { to introduce curtains as light and } \\
\text { ephemeral partition elements } \\
\text { in order to create different } \\
\text { spatial configurations. Specific } \\
\text { requirements of users and } \\
\text { simultaneous use of space were } \\
\text { achieved by various dispositions } \\
\text { of curtains. }\end{array}$ & \\
\hline \multirow{2}{*}{$\begin{array}{l}\text { Central space } \\
\text { Intervention No. } 2\end{array}$} & Multifunctional Table & \\
\hline & $\begin{array}{l}\text { This proposal introduces a } \\
\text { dominant element positioned } \\
\text { in the central space in the form } \\
\text { of a large assembly modular } \\
\text { table. It is possible to be used } \\
\text { for the requirements of fashion } \\
\text { design, workshops, or different } \\
\text { types of panel discussions, work } \\
\text { groups, and presentations. The } \\
\text { height of the space ( } 6 \mathrm{~m}) \text { enables } \\
\text { the positioning of necessary } \\
\text { scenography in a way that space } \\
\text { can also be used as a small stage } \\
\text { for performances. This concept } \\
\text { also allows positioning a bar in } \\
\text { order to transform the space into an } \\
\text { informal gathering space. }\end{array}$ & \\
\hline \multirow{2}{*}{$\begin{array}{l}\text { Central Space } \\
\text { Intervention No. } 3\end{array}$} & Warehouse within the Warehouse & \\
\hline & $\begin{array}{l}\text { Due to the adequate space } \\
\text { height, students also proposed } \\
\text { interventions which apply to } \\
\text { different possibilities of using } \\
\text { spatial capacities of a warehouse } \\
\text { vertically. This would enable } \\
\text { storing many materials and } \\
\text { equipment that are crucial for } \\
\text { organizing numerous events which } \\
\text { take place inside this space. }\end{array}$ & \\
\hline
\end{tabular}




\section{Office Space Art + Cinema + Office}

Intervention No. 4

By removing partition walls, it is possible to accomplish merging of office space promoting a more flexible use. With regard to this, the capacity of merged spaces enables forming the cinema, with a rather simple sitting disposition and position of a movie screen. Since there is no need for perpetual movie projections, this proposal offers the possibility to be used both as a cinema, but also as a working space.

Dance Hall Dance Hall

Intervention No. 5 Dance performances and acrobatics are the most prevalent activities in this space, thus they are treated with special attention. The absence of spatial elements (such as columns and partition walls) is precisely what enables efficient and uninterrupted performance of dance activities. The crucial intervention is related to the introduction of dressing rooms which offer additional comfort to the users of this space. Other interventions are related to the improvement of various technical conditions (insulation, lighting, climatisation, ventilation) which also enhance the quality of conditions for performing the aforementioned activities.

Integrated zones Dialogue between the

Intervention No. 6 interior and exterior

Forming space from exterior towards interior, or vice-versa inevitably provokes a necessary tension for conceiving architecture. Therefore, this type of intervention is based on the extension of a spatial framework of the warehouse by integrating it with the exterior space. Connecting and integrating the interior and exterior space is achieved by the fluidity of a space which promotes designed continuity between the exterior and the interior.
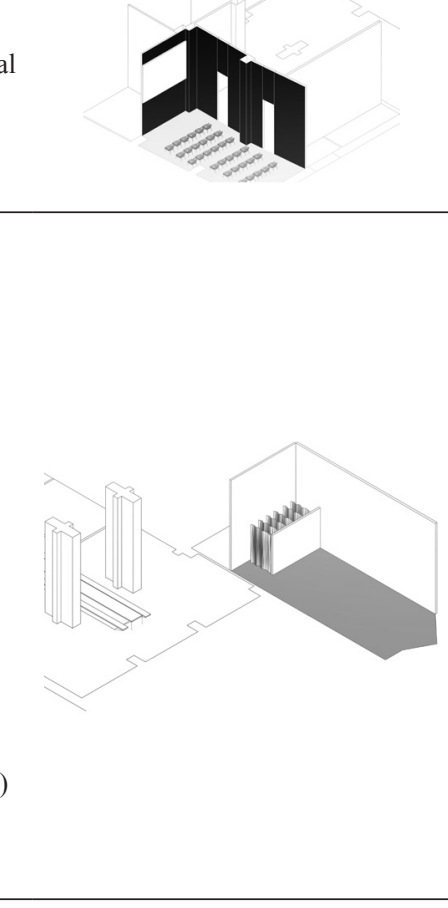
Since the initial task was related to creating different types of transformation for the existing space, the following phase involved the analysis of students' proposals based on previously defined transformation principles from the theoretical framework (Table 2). This analysis also proved to be useful for the identification of different models of adaptation, which are an integral part of the transformation-based framework, due to their possibility of dynamic changes. This way of analyzing simultaneously promotes research about specific design approaches, in the context of applying transformation principles. In this sense, within the domain of typical proposals, the predominant use of certain principles was recognized and further clarified.

Table 1. Analysis of the proposals depending on the application of the transformation principle

\begin{tabular}{ll}
\hline INTERVENTION & EXPLANATION OF APPLIED PRINCIPLES \\
\hline Curtain Walls & The open plan principle is interpreted through the potential of \\
The open plan principle & $\begin{array}{l}\text { different spatial configurations which involves placing partitions. } \\
\text { The advantages of this proposal can be perceived through the } \\
\text { possibilities of performing parallel activities which do not require } \\
\text { sound insulation. Also, it is significant to mention the possibility of } \\
\text { complete removal of partitions, which enables, other than specific } \\
\text { activities, the extension of the plan, i.e. integration with the entire } \\
\text { interior space, but the exterior, as well. }\end{array}$
\end{tabular}

Curtain Walls This element also contains another important aspect, and it is

Improvisation principle connected with the introduction of the improvisation principle. The improvisation principle treats space in a more flexible manner, and it enables constant changes according to various needs. By applying this ephemeral element specifically, users can transform the space based on their personal needs. Therefore, users become more involved in defining "new boundaries" of the space and its unmarking.

\begin{tabular}{ll}
\hline $\begin{array}{l}\text { Multifunctional Table } \\
\text { The mobility principle }\end{array}$ & $\begin{array}{l}\text { The mobility principle in this example is applied through the } \\
\text { possibility of movable elements which imply the possibility of } \\
\text { multiple ways of use. If there is a need for a new spatial element } \\
\text { which can perform different functions, it elevates from the floor } \\
\text { level, otherwise, it stays on the floor level. }\end{array}$ \\
\hline $\begin{array}{l}\text { Multifunctional Table } \\
\text { The interaction } \\
\text { principle }\end{array}$ & $\begin{array}{l}\text { It is necessary to emphasize that if the multifunctional table is } \\
\text { active, it becomes a sculptural element, which possesses both a } \\
\text { metaphorical and a social aspect. Namely, the users and audience } \\
\text { move around it, observe it, use it in various ways, thus making it } \\
\text { an interactive element, which, at the same time, engages numerous } \\
\text { metaphors that initiate contemplation about this element. }\end{array}$ \\
\hline $\begin{array}{l}\text { Multifunctional Table } \\
\text { The modularity and } \\
\text { prefabrication principle }\end{array}$ & $\begin{array}{l}\text { The modularity and prefabrication principles are less dominant in } \\
\text { this proposal and are only used in the context of rationalization and } \\
\text { optimization of construction elements which make the table. The } \\
\text { modular aspect of the structure also enables different dimensions of } \\
\text { this element, which changes the character of the perceived space. }\end{array}$ \\
\hline
\end{tabular}




\begin{tabular}{|c|c|}
\hline $\begin{array}{l}\text { Multifunctional Table } \\
\text { The open plan principle }\end{array}$ & $\begin{array}{l}\text { The open plan principle is achieved through different possibilities } \\
\text { of transforming the given spatial configuration depending on the } \\
\text { position of the table. This especially highlights the polyvalence, or } \\
\text { more precisely, the occurrence of various programs according to } \\
\text { specific needs of users. }\end{array}$ \\
\hline $\begin{array}{l}\text { Warehouse Within the } \\
\text { Warehouse }\end{array}$ & \multirow{2}{*}{$\begin{array}{l}\text { The modularity principle is applied with an objective to store } \\
\text { equipment more effectively and rationally, and it is achieved by } \\
\text { designing modular elements which can be either opened or closed. } \\
\text { Access to these modules is achieved by using movable ladders. It is } \\
\text { relevant to highlight the possibility of extension or reduction of the } \\
\text { structure by adding or eliminating modular element, with the main } \\
\text { aim to store a large amount of equipment and materials as effectively } \\
\text { as possible. }\end{array}$} \\
\hline $\begin{array}{l}\text { The modularity } \\
\text { principle }\end{array}$ & \\
\hline $\begin{array}{l}\text { Warehouse Within the } \\
\text { Warehouse }\end{array}$ & \multirow{2}{*}{$\begin{array}{l}\text { The open plan principle can be recognized according to the entire } \\
\text { dimensions of the building, which, as a result of its significant } \\
\text { height, enables the production of contents within different plans. } \\
\text { This aspect of space is crucial during the occurrence of various } \\
\text { dance performances, acrobatics, but other activities that were } \\
\text { mentioned in the interviews, as well. }\end{array}$} \\
\hline The open plan principle & \\
\hline $\begin{array}{l}\text { Art }+ \text { Cinema }+ \text { Office } \\
\text { The open plan principle }\end{array}$ & $\begin{array}{l}\text { Removal of partition walls enables the flexible use of the space } \\
\text { which enhances the functioning of different concepts and it actively } \\
\text { corresponds with the previously mentioned needs. In this sense, the } \\
\text { use of the open plan is essential, precisely through the potential of } \\
\text { expansion, but through polyvalence, as well. Users' requirements } \\
\text { decreasingly include traditional possibilities of space use, thus the } \\
\text { open plan enables different spatial formations based on different } \\
\text { specific needs. Additionally, expansion of the space also offers } \\
\text { the possibility to perform different actions, which promotes the } \\
\text { polyvalence. }\end{array}$ \\
\hline $\begin{array}{l}\text { Dance Hall } \\
\text { The ephemerality and } \\
\text { modularity principle }\end{array}$ & $\begin{array}{l}\text { In the proposed intervention, the use of the ephemerality and } \\
\text { modularity principle can be recognized through the introduction of } \\
\text { modular elements with an ephemeral character. Namely, the new } \\
\text { structure, which provides comfort to its users, is introduced within } \\
\text { the dance hall. The design of modular dressing rooms meets the } \\
\text { requirements of the users, and their modular aspect keeps the space } \\
\text { from being determined and leaves the possibility for new formations. }\end{array}$ \\
\hline $\begin{array}{l}\text { Conjunction of the } \\
\text { interior and exterior } \\
\text { space } \\
\text { The mobility principle }\end{array}$ & $\begin{array}{l}\text { The link between the interior and exterior space is achieved as } \\
\text { a result of the fluidity of the space which provides the harmonic } \\
\text { relation between these zones. This way, the modularity principle is } \\
\text { introduced and it entirely redefines the boundary between the interior } \\
\text { and exterior space. The exterior space correlates with the interior, the } \\
\text { outside becomes the expression of the inside which defines the form } \\
\text { and the concept of the exterior. This provides the dialogue between } \\
\text { the external and internal zones, it encourages the fluid character, and } \\
\text { it enables the specific interpretation of the relation between these } \\
\text { zones, which was implied by the fluidity. }\end{array}$ \\
\hline
\end{tabular}




\section{DISCUSSION}

Students' proposals differ depending on the proposed programmatic and formal characteristics, as well as specific zones of intervention (Table 1). All types of interventions have an adaptable character in common, based on the users' needs, and it offers a variety of sustainable use scenarios. Regarding this, the affirmation of the hypothesis, which implies that the application of transformation principles is becoming an integral part of a methodological apparatus in the context of activation of unused spatial resources, can be perceived. Through the results of the workshop, the mutual connections, as well as the transformation principles, are being set, which more particularly define the conceptual framework of activation of unused spatial resources. Merging of different proposals, that relate to this issue, proposes the development of new transformation models, which could react to the specific problems and requirements of the surroundings in an unspecified moment.

Most of the students' proposals referred to the elaboration of individual zones within the space of "Magacin". The central space of the warehouse was marked as the host of the highest number of various activities, where some occur rather frequently and simultaneously, thus the majority of interventions involved taking this space into consideration. The office space gained its polyvalent character due to the removal of partition walls, i.e. it gained the possibility to change its function depending on users' needs. The dance hall represents an ambiance which is also perceived as polyvalent as a result of its neutral character, but the primary purpose was defined by its dominant function. Several proposals offered the possibility to integrate previously mentioned zones, and observe them as a whole, which might be curious in the context of the following research. The results of the workshop created a platform for the development and examination of different transformation models in the form of a prototype which could be applied to other similar case studies. The transformation phenomenon is explained through the classification of various dynamic principles, which clarify and conceptualize the activation of unused spatial resources (Table 2). The interaction with the users of the space, and proposing an adequate solution which satisfies their specific needs, represents a very significant indicator and supplement for different proposed interventions.

Regarding the focus and the relevance of the research, the open plan and improvisation principles could be singled out as the predominant ones. The open plan principle can be recognized, in the context of this research, through the universal need for a flexible spatial configuration aiming to acknowledge different dynamic changes, according to volatile users' preferences. The notions 
of multifunction, or polyvalence, are related to the identification of different programs which could change over the period of time. The variability of the way space is used represents a relevant factor for the analysis of the design conceptions in the context of identifying the open plan principles. In spite of the fact that a certain type of indefiniteness, or the possibility of unpredictable ways of use, is present, it is significant to consider this potential in the process of design.

Through the remarkably important dialogue with the users, it can be deduced that the improvisation principle has a high level of presence in all proposals and that its application is rather significant. In this context, the improvisation principle represents a form of a creative dialogue between the users and the author, as a synthesis model which takes place in the formation of the final outcome. This kind of approach valorizes the social aspect and promotes the distinctive character of the creation process, which entirely depends on the interaction of all participators and it dictates the quality of the space. The application of the principle of continuous improvisation places architecture structures under the constant process of transformation.

It is also relevant to emphasize how the perceived compatibility of principles shapes the conceptual framework for defining different synthetic models for adaptive reuse of spaces which were created under the influence of transformation principles. As the main thesis, the possibility of improving the characteristics of individual principles is being imposed, through the synthesis with other compatible principles. This way, the definition of more transformable models is being enabled, which are able to accept a greater variety of changes. The relations between the open plan principle and other principles are particularly distinguished, thus certain models are being formed based on the dominant aspects of integral transformation principles:

Mode1 1: occurs as an integration of open plan and improvisation principle

The main aspects of this model relate to the application of different concepts which promote the open plan and the improvisation principle, with a scope of the perpetual transformation of spaces. The model is dynamic and programmed in a way that it can be reconfigured at any moment according to the new needs. The conceptual framework, which is generated in this manner, carries a certain dose of indefiniteness that occurs as a result of different needs, desires, and decisions of users with a specific esthetics which emanates from this concept. 
Mode1 2: occurs as an integration of open plan and mobility principle This model is defined with flexibility which is demonstrated in the possibility to move the elements, i.e. it introduces different kinetic potentials of segments or the whole, which latter generate the ability to adapt to different conditions or users' needs. It can also relate to establishing different flows of movement according to which spatial and functional aspects are being conceived within the design process.

Mode1 3: occurs as an integration of open plan and ephemerality principle

In this model, the application of the open plan principle relates to the notion of polyvalence, concerning the introduction of events, different activities, or specific programs which provide the conceptual framework with an activation of the space. In addition, it is relevant to highlight the due date in terms of possibility of adapting to users needs in a short period of time. Accordingly, the recycling of the space, as well as the intervention within the space itself, are being promoted.

Other than generating diverse domains of interventions, it can be concluded that transformation models vary within the time framework that is within the time limit. In this context, two types of interventions can be distinguished, the short-termed interventions (ephemeral), that have a due date, and the permanent ones, which involve radical space alterations. It is important to emphasize that possibilities of ephemeral, short-termed interventions, that have a due date, influence the creation of more effective long-term strategies in the context of activating a certain space since they don't require large investments. According to the analyzed theoretical framework, the listed models can be assigned with different interpretations in the context of further activation of unused spatial resources.

Additionally, it is important to highlight that considering different principles of transformation, and their implementation within the design methodologies, do not promote the standardization of an architecture practice, nor offer a concluded solution. On the contrary, it aims to expand the design processes in the context of the philosophy of sustainable development. The workshop results, as a methodical model of research, simultaneously represent new methodological apparatus for the design and activation of unused spatial resources through diversity and the possibility to integrate or simultaneously apply different creative solutions. It should also be emphasized how listed ways of the transformation of unused spatial resources do not represent a determined 
approach to architectural design, instead, they aim to establish a sustainable architectural and urban platform, which could encourage further research, but also application within the boundaries of contemporary design methodologies.

\section{CONCLUSION}

Finally, it is important to explain specific contributions of this research and the methodological procedure, but also the limitations which appear within the boundaries of this methodological approach. Other than the general contribution to the domain of urban and architectural design, as well as to the area of urban regeneration and revitalization, including both theoretical and empirical aspect equally, the specific contribution also concerns defining the methodological approach which involves examining the role of transformation and possible mechanisms that could be used for the activation of unused spatial resources. Significant contribution also refers to the detailed analysis of the theoretical and practical approach to the appointed issue, which opens up new possibilities on the micro-level in terms of activating unused spatial resources. Namely, by providing these findings, rethinking of the approach to the activation of spatial resources is enabled, and it indicates the specificities and limitations of the process itself. The key contribution lies in connecting micro- and macro-levels, i.e. examining the dependence of transformation models for unused spatial resources in the context of sustainable urban development. Having this in mind, according to the thematic feature of the paper, the structure is complemented by the results of the student workshop which are, within this context, considered as a starting point for further development of the methodological approach, rather than a final outcome. It is necessary to emphasize that the deficiencies, which are assigned to this methodological approach due to its subjectivity and unreliableness of the information during its interpretation process, are avoided as a result of the choice of interviewees and interpretation of theoretical and practical findings. Furthermore, it should be mentioned that the selective observation and subjective interpretation of the researcher were avoided as a result of the firm theoretical framework throughout the application of the case study method, which actually served as a control mechanism for the validity of the workshop results.

The limitations of this research refer to the single analysis inside the local context since the comparative analysis of multiple cases would be significant for the relation between the micro- and the macro-level, and it would involve the use of the same apparatus for comparing the information collected from different cases. The difference between the individual case and the study of 
multiple cases is exactly the increase of information which requires precise systematization of the data, based on which the comparison can be made and the generalization can be enabled. Therefore, the research and the methodological approach developed in that manner, provide the possibility for systematization and validity of the data which refer to a broader context. The development of the approach, which reflects on increasing number of specific studies, and on the application of these results within practice, would enable a more precise and firm base for future approaches to the activation of spatial resources, but the improvement of findings within the domain of architectural and urban design, as well. The use and significance gained through this research can be used as the initial material for further examination of possible models within different local contexts, with the main scope to more effectively use spatial resources, which is directly connected to the sustainable urban development. and social aspects of developing settlements and climate change - mutual impacts" (TR36035), financed by the Ministry of Education and Science of the Republic of Serbia for the period 20112016. The student workshop was part of the project "Let's save Magacin" of the Association Independent Cultural Scene of Serbia, financed by Regional Platform for Culture Kooperativa. 
P. F. Cherchi, "Adaptive Reuse of Abandoned Monumental Buildings as a Strategy for Urban Liveability,” Athens Journal of Architecture 1 (4) (2015): 253-270.

K. Danilović, B. Stojkov, S. Zeković, Ž. Gligorijević and D. Damjanović, Oživljavanje braunfilda u Srbiji (Beograd: Palgo centar, 2008).

I. Čukić, "Uloga privremenih urbanih praksi u aktiviranju prostornih resursa" (Ph.D. Thesis, University of Belgrade, Belgrade, Serbia, 2016).

K. Danilović, B. Stojkov, S. Zeković, Ž. Gligorijević and D. Damjanović, Oživljavanje braunfilda u Srbiji.

K. Pantović, "Uloga principa transformacije u razvoju projektantskih modela u arhitektonskom projektovanju" (Ph.D. Thesis, University of Belgrade, Belgrade, Serbia, 2016).

A. Nikezić and D. Marković, "Place-Based Education in the Architectural Design Studio: Agrarian Landscape as a Resource for Sustainable Urban Lifestyle," Sustainability 7 (2015): 9711-9733.

Z. Bauman, Fluidni život (Novi Sad: Mediterran Publishing, 2009).

I. Čukić, "Uloga privremenih urbanih praksi u aktiviranju prostornih resursa"

K. Danilović, B. Stojkov, S. Zeković, Ž. Gligorijević and D. Damjanović, Oživljavanje braunfilda u Srbiji, 53-60.

Sl. glasnik RS, br. 88/2010. Prostorni plan Republike Srbije od 2010. do 2020. Available online: http://www.rapp.gov.rs/Storage/Global/Documents/2015/E80/Tekst\%20plana.pdf (Accessed on 20 October 2015).

M. Vujošević, "Stranputice državne politike prostornog razvoja: neosnovane nade, lažna obećanja i nepostojanje stvarnih instrumenata." Polis 1(1) (2012): 27-31.

J. W. Dorsey, "Brownfields and Greenfields: The Intersection of Sustainable Development and Environmental Stewardship," Environmental Practice 5(1) (2003): 69-76.

J. E. Innes, "Indicators for sustainable development: a strategy building on complexity theory and distributed intelligence," Planning Theory and Practice 1(2) (2000): 173-186; V. Nadin, and C. Brown, S. Duhr, Sustainability, Development and Spatial Planning in Europe (London: Routledge: 2001).

G. De Roo and G. Porter, eds., Fuzzy Planning: The Role of Actors in a Fuzzy Governance Environment; Abingdon, Oxon: Ashgate Publishing Group, 2007).

D. Konstantinović, "Programske osnove održive arhitekture - Slučaj savremenih poslovnih zgrada," Nauka + praksa 12 (2009): 8-11.

P. Reeves, An introfuction to social housing (Oxford: Elsevier, 2005).

T. Elkin, D. McLaren and M. Hillman, Reviving the City: towards sustainable urban development (London: Friends of the Earth, 1991): 12.

S. Baker, Sustainable development (New York, USA: Routledge, 2006): 8.

S. Perović, N., Kurtović-Folić, "Bronwfield regeneration - imperative for sustainable urban development," Građevinar 64/5 (2012): 373-383.

K. Pantović, "Uloga principa transformacije u razvoju projektantskih modela u arhitektonskom projektovanju".

K. Frempton, Moderna arhitektura, kritička istorija (Beograd: Orion art, 2004); N. Linton,

'Futurizam," in Antologija moderne arhitekture, ed. M. Perović (Beograd: Draslar partner, 2005), $17-22$.

A. Codrescu and J. Siegal, Mobile: The Art of Portable Architecture (New York: Princeton Architectural Press, 2002).

Y. Friedman, Yona Friedman / Pro Domo (Barcelona: Actar, 2006).

M. Wigley, Constant's New Babylon: The Hyper-Architecture of Desire (Roterdam: 010 Publishers, 1998).

K. Pantović, "Sustainability of Temporary Structure Models Designed for Housing" in Regional Development, Spatial Planning and Strategic Governance (RESPAG 2013 - Proceedings of the 2nd International Scientific Conference; Belgrade, Serbia, Institute of Architecture and Urban \& Spatial Planning of Serbia (IAUS), Belgrade, Serbia, 2013) 1081-1086. 
G. Delalex, Go with the flow - Architecture, infrastructure, and everyday experience of mobility (Vaajakoski, Finland: University of Art and Design Helsinki, 2006).

Z. Bauman, Fluidni život.

T.D. Miller and P. Elgård, "Defining Modules, Modularity and Modularization. Evolution of the Concept in a Historical Perspective," in Design for Integration in Manufacturing (Proceedings of the 13th IPS Research Seminar, Fuglsoe 1998, Aalborg, Denmark, 1998.; Aalborg University: Aalborg, Denmark, 1998).

D. Mertins, "Same Difference," in Phylogenesis: foa `s ark, eds. A. Zaera-Polo and F. Moussavi (Barcelona: Actar, 2003), 270-279.

Heikkinen, T. Design Research and Housing. In Design connections - knowledge, value and involment through design; Keinonen, T.; University of Art and Design Helsinki, Helsinki, Finland, 2008.; pp. 64-78.

Ibid.

B. Tschumi, Architecture and Disjunction (Cambridge, USA: MIT Press, 1996).

Z. Bauman, Fluidni život.

A. Andia and T. Spiegelhalter, Post-Parametric Automation in Design and Construction (Norwood, Massachusetts, USA: Artech House, 2015).

K. Pantović, Uloga principa transformacije.

C. Jencks and N. Silver, Adhocism: The Case for Improvisation (Cambridge, Massachusetts, USA: The MIT Press: 2013).

I. Čukić, Uloga privremenih urbanih praksi.

I. Čukić, Mapa akcije (Beograd: Creative Lab, 2013).

I. Čukić, Uloga privremenih urbanih praksi.

V.Milosavljević, "Magacin u Kraljevića Marka," Manek 4 (2015): 28-33.

Ibid. 
Andia, Alfredo and Thomas Spiegelhalter. Post-Parametric Automation in Design and Construction. Norwood, Massachusetts: Artech House, 2015.

Baker, Susan. Sustainable development. New York: Routledge, 2006.

Bauman, Zigmunt. Fluidni život. Novi Sad: Mediterran Publishing, 2009.

Borislav, Stojkov. "Oživljavanje braunfilda." In Oživljavanje braunfilda u Srbiji, autor Klara Danilović, Borislav Stojkovi, Slavka Zeković, Žaklina Gligorijević i Dušan Damjanović, 5360. Belgrade: Palgo centar, 2008.

Broos, L., T. Ertel, A. Gray, B. Schug, i J. (Eds.) (2007). Vegter. "European Brownfield Revitalisation Agenda." Accessed 2013. http://www.eubra.eu, 2007.

Broos, Luc, Thomas Ertel, Andrew Gray, Bettina Schug and Joop Vegter. "European Brownfield Revitalisation Agenda." (2007) Accessed February 2013.

Cherchi, Pier Francesco. "Adaptive Reuse of Abandoned Monumental." Athens Journal of Architecture 1 (2015): 27-43.

Čukić, Iva. Mapa akcije. Belgrade: Creative Lab, 2013.

Čukić, Iva. "Uloga privremenih urbanih praksi u aktiviranju prostornih resursa." Phd diss., University of Belgrade, 2016.

Danilović, Klara, Borislav Stojkov, Slavka Zeković, Žaklina Gligorijević, and Dušan Damjanović. Oživljavanje braunfilda u Srbiji. Belgrade: Palgo centar, 2008.

De Roo, Gert, and Geof Porter. Fuzzy Planning: The Role of Actors in a Fuzzy Governance Environment. Abingdon, Oxon: Ashgate Publishing Group, 2007.

Delalex, Gilles. Go with the flow - Architecture, infrastructure, and everyday experience of mobility. Vaajakoski: University of Art and Design Helsinki, 2006.

Dorsey, Joseph William. "Brownfields and Greenfields: The Intersection of Sustainable Development and Enviromental Stewardship." Enviromental Practice 5 (2003), 69-76.

Elkin, Timothy, Duncan Mclaren, and Mayer Hillman. Reviving the City: Towards Sustainable Urban Developmen. London: Friends of the Earth, 1991.

Friedman, Yona. Yona Friedman / pro Domo. Barcelona: Actar, 2006.

Heikkinen, Tero. "Design Research and Housing." In Design connections: Knowledge, value and involment through design, edited by Turkka Keinnonen, 64-78. Helsinki: University of Art and Design Helsinki, 2008.

Innes, Judith Eleanor. "Indicators for sustainable development: a strategy building on complexity theory and distributed intelligence." Planning Theory and Practice 1 (2000): 173-186.

Jencks, Charles and Nathan Silver. Adhocism: The Case for Improvisation. Cambridge: The MIT Press, 2013.

Konstantinović, Dragana. "Programske osnove održive arhitekture - Slučaj savremenih poslovnih zgrada." Nauka+praksa 12.2 (2009) 8-11.

Linton, Norbert. "Futurizam.” In Antologija moderne arhitekture, edited by Miloš Perović, 17-22. Belgrade: Draslar partner, 2005.

Maas, Winy. Five Minutes City. Architecture and (Im)mobility Forum \& Workshop Rotterdam. Roterdam: Ram Distribution, 2007.

Mertins, Detlef. “Same Difference.” In Phylogenesis: foa 's ark, Alejandro Zaera-Polo and Farshid Moussavi , 270-279. Barcelona: Actar, 2003.

Miller, Thomas Dedenroth. "Defining Modules, Modularity and Modularization: Evolution of the Concept in a Historical Perspective." Design for Integration in Manufacturing. Proceedings of the 13th IPS Research Seminar Fuglsoe 1998. Aalborg: Aalborg University, 1998.

Milosavljević, Vesna. “Magacin u Kraljevića Marka.” Manek 28-33, 2015.

Nadin, Vincent, Caroline Brown, and Stefanie Duhr. Sustainability, Development and Spatial Planning in Europe. London: Routledge, 2001.

Nikezić, Ana and Dragan Marković. "Place-Based Education in the Architectural Design Studio: Agrarian Landscape as a Resource for Sustainable Urban Lifestyle.” Sustainability 9711-9733, 2015. 
Pantović, Ksenija. "Sustainability of Temporary Structure Models Designed for Housing." Regional Development, Spatial Planning and Strategic Governance RESPAG 2013 - Proceedings of the 2nd International Scientific Conference. 1081-1086. Belgrade: Institute of Architecture and Urban \& Spatial Planning of Serbia (IAUS), 2013.

Pantović, Ksenija. "Uloga principa transformacije u razvoju projektantskih modela u arhitektonskom projektovanju." Pdh diss., University of Belgrade, 2016.

Pantović, Ksenija, and Jasna Kavran. "Uloga principa transformacije u arhitektonskom projektovanju.” In Prostorni, ekološki, energetski i društveni aspekti razvoja naselja i klimatske promene, Mila Pucar and Marina Nenković-Riznić, 33-46. Belgrade: Institut za arhitekturu i urbanizam, 2016.

Perović, Svetlana, and Nađa Kurtović-Folić. "Brownfield regeneration-imperative for sustainable urban development." Građevinar 64 (2012): 373-383.

Reeves, Paul. An introduction to social housing. Oxford: Elsevier, 2005.

Sassen, Saskia. "The global city: introducing a concept." Brown Journal of World Affairs 11 (2005): 27-43.

Siegal, Jennifer, and Andrei Cordescu. Mobile: The Art of Portable Architecture. New York: Princeton Architectural Press, 2002.

Tschumi, Bernard. Architecture and Disjunction. Cambridge: MIT Press, 1996.

Vujošević, Miodrag. "Stranputice državne politike prostornog razvoja: neosnovane nade, lažna obećanja i nepostojanje stvarnih instrumenata." Polis 1 (2012): 27-31.

Wigley, , Mark. Constant's New Babylon: The Hyper-Architecture of Desire. Roterdam: 010 Publishers, 1998 


\section{RAZMERA NA PAPIRU IZMEDJU TEHNIKE I IMAGINACIJE. PRIMER KONSTANTOVE CRTAČKE PRETPOSTAVKE \\ Anđelka Bnin-Bninski, Maja Dragišić}

Postupak razmeravanja je jedna od osnovnih radnji u arhitektonskom crtanju. Uz papir kao kao osnovni materijal za crtanje, razmera predstavlja arhitektonsku konvencija odmah po samom crtanju u arhitekturi Renesanse. U ovom radu ispituje se procedura razmeravanja iz pozicije crteža u idejno-stvaralačkom arhitektonskom procesu. Aktuelna teorijska istraživanja o arhitektonskom crtežu ističu promenu paradigme koja se dogodila usled iznenadnog prelaska sa ručnog na kompjuterski crtež. Ova promena je posledično uticala na materijalni značaj crtanja/crteža, odnosa prema razmeri i geometriji. Argumentujući razmeru kao dvoznačnu radnju, tehničku i kreativnu, Konstantovi crteži Novog Vavilona uzeti su kao primer problematizacije relacionog lanca arhitekta - projekat - objekat.

KLJUČNE REČI: ARHITEKTONSKI CRTEŽ, RAZMERA, PAPIR, CRTEŽ STANOVANJA, KONSTANTOV NOVI VAVILON

\section{IZVAN PROPORCIJA \\ Reinterpretacija proporcija - između konceptualnog $i$ \\ perceptivnog mišijenja arhitekture \\ (komunikativna dimenzija grada)}

\section{Miloš Mihajlović, Aleksandra Subotić, Vladimir Parežanin}

Rad posmatra proporcuju kao alat kojim se urbanista i arhitekta koriste da bi se postigao određeni kvalitet prostora. Kako se kroz proporciju posmatraju odnosi celine i njenih delova, tako rad sagledava aspekte prostora od prostornog plana grada do arhitektonskog detalja. Takođe, i pored toga što je proporcija odnos dimenzija fizičkih elemenata u prostoru, rad razmatra proporciju i kroz odnos materijalnih i nematerijalnih aspekata prostora. Na taj način, težište rada je pomereno na nivo komunikacije između arhitektonsko-urbanističkog prostora i njegovih korisnika, odnosno na orkestraciju kroz percepciju i doživljaj prostora, a ne na prevaziđenu, proporcijsku analizu arhitektonske forme.

KLJUČNE REČI: ARHITEKTONSKO PROJEKTOVANJE, ISTRAŽIVANJE KROZ DIZAJN, ODNOS, PROPORCIJE, ESTETIKA, MODULOR, REZILIJENTNOST

\section{MODELI TRANSFORMACIJE NEISKORIŠČENIH PROSTORNIH RESURSA Istraživačka studija KC Magacin u Beogradu \\ Ksenija Pantović, Iva Čukić}

Ovaj rad istražuje različite modele transformacije neiskorišćenih prostornih resursa, u cilju prepoznavanja aspekata koji vode održivom aktiviranju prostora. Značaj istraživanja ogleda se i u naučnoj interpretaciji i pojašnjenju fenomena transformacije $u$ aktiviranju neiskorišćenih prostornih resursa, i to u kontekstu post-socijalističke Srbije sa posebnim fokusom na glavni grad. Istovremeno, ovaj rad predstavlja i doprinos metodologiji arhitektonskog projektovanja, kroz ukazivanje na značaj primene modela transformacije u projektantskom procesu. U tom kontekstu, teorijski okvir istraživanja se odnosi na različite aspekte urbane održivosti u kontekstu aktiviranja neiskorišćenih prostornih resursa, kao i na dublje razjašnjavanje uloge principa transformacije u arhitektonskom diskursu. Empirijski deo istraživanja se odnosi na analizu studije slučaja konkretnog prostornog okvira Kulturnog centra Magacin u Beogradu i to metodom sprovođenja studentske radionice. Studenti istražuju različite mogućnosti transformacije i aktivacije prostora, kroz niz predloženih intervencija. Završni deo rada obuhvata sintezu i interpretaciju rezultata u odnosu na kontekst istraživanja i postavljene problemske postavke, ali što je značajnije, daje stepen uslovljenosti 


\section{RAZMERA NA PAPIRU IZMEDJU TEHNIKE I IMAGINACIJE. PRIMER KONSTANTOVE CRTAČKE PRETPOSTAVKE \\ Anđelka Bnin-Bninski, Maja Dragišić}

Postupak razmeravanja je jedna od osnovnih radnji u arhitektonskom crtanju. Uz papir kao kao osnovni materijal za crtanje, razmera predstavlja arhitektonsku konvencija odmah po samom crtanju u arhitekturi Renesanse. U ovom radu ispituje se procedura razmeravanja iz pozicije crteža u idejno-stvaralačkom arhitektonskom procesu. Aktuelna teorijska istraživanja o arhitektonskom crtežu ističu promenu paradigme koja se dogodila usled iznenadnog prelaska sa ručnog na kompjuterski crtež. Ova promena je posledično uticala na materijalni značaj crtanja/crteža, odnosa prema razmeri i geometriji. Argumentujući razmeru kao dvoznačnu radnju, tehničku i kreativnu, Konstantovi crteži Novog Vavilona uzeti su kao primer problematizacije relacionog lanca arhitekta - projekat - objekat.

KLJUČNE REČI: ARHITEKTONSKI CRTEŽ, RAZMERA, PAPIR, CRTEŽ STANOVANJA, KONSTANTOV NOVI VAVILON

\section{IZVAN PROPORCIJA \\ Reinterpretacija proporcija - između konceptualnog $i$ \\ perceptivnog mišijenja arhitekture \\ (komunikativna dimenzija grada)}

\section{Miloš Mihajlović, Aleksandra Subotić, Vladimir Parežanin}

Rad posmatra proporcuju kao alat kojim se urbanista i arhitekta koriste da bi se postigao određeni kvalitet prostora. Kako se kroz proporciju posmatraju odnosi celine i njenih delova, tako rad sagledava aspekte prostora od prostornog plana grada do arhitektonskog detalja. Takođe, i pored toga što je proporcija odnos dimenzija fizičkih elemenata u prostoru, rad razmatra proporciju i kroz odnos materijalnih i nematerijalnih aspekata prostora. Na taj način, težište rada je pomereno na nivo komunikacije između arhitektonsko-urbanističkog prostora i njegovih korisnika, odnosno na orkestraciju kroz percepciju i doživljaj prostora, a ne na prevaziđenu, proporcijsku analizu arhitektonske forme.

KLJUČNE REČI: ARHITEKTONSKO PROJEKTOVANJE, ISTRAŽIVANJE KROZ DIZAJN, ODNOS, PROPORCIJE, ESTETIKA, MODULOR, REZILIJENTNOST

\section{MODELI TRANSFORMACIJE NEISKORIŠČENIH PROSTORNIH RESURSA Istraživačka studija KC Magacin u Beogradu \\ Ksenija Pantović, Iva Čukić}

Ovaj rad istražuje različite modele transformacije neiskorišćenih prostornih resursa, u cilju prepoznavanja aspekata koji vode održivom aktiviranju prostora. Značaj istraživanja ogleda se i u naučnoj interpretaciji i pojašnjenju fenomena transformacije $u$ aktiviranju neiskorišćenih prostornih resursa, i to u kontekstu post-socijalističke Srbije sa posebnim fokusom na glavni grad. Istovremeno, ovaj rad predstavlja i doprinos metodologiji arhitektonskog projektovanja, kroz ukazivanje na značaj primene modela transformacije u projektantskom procesu. U tom kontekstu, teorijski okvir istraživanja se odnosi na različite aspekte urbane održivosti u kontekstu aktiviranja neiskorišćenih prostornih resursa, kao i na dublje razjašnjavanje uloge principa transformacije u arhitektonskom diskursu. Empirijski deo istraživanja se odnosi na analizu studije slučaja konkretnog prostornog okvira Kulturnog centra Magacin u Beogradu i to metodom sprovođenja studentske radionice. Studenti istražuju različite mogućnosti transformacije i aktivacije prostora, kroz niz predloženih intervencija. Završni deo rada obuhvata sintezu i interpretaciju rezultata u odnosu na kontekst istraživanja i postavljene problemske postavke, ali što je značajnije, daje stepen uslovljenosti 
promena na mikro-nivou (modeli transformacije neiskorišćenih prostornih resursa) kontekstom makro-nivoa (aktiviranje prostora u odnosu na aspekte održivog urbanog razvoja).

KLJUČNE REČI: MODELI TRANSFORMACIJE, PRINCIPI TRANSFORMACIJE, NEISKORIŠĆENI PROSTORNI RESURSI, URBANA ODRŽIVOST, KULTURNI CENTAR MAGACIN, STUDENTSKA RADIONICA

\section{RELACIONE LOGIKE I DIJAGRAMI: STANJA BEZ RAZMERE (NEMETRIČKA STANJA) Dragana Ćirić}

Studija razmatra logike relacionog mišljenja i konektivnosti, prikazujući odnose između predmeta reprezentacije i načine njegovog predstavljanja u crtežima, dijagramima, mapama i notacijama, koje ili negiraju razmeru i metrička svojstva, ili funkcionišu u svim razmerama ne pripadajući isključivo ni jednoj od njih. Obuhvataju korelacije i proporcije (statičke i dinamičke, geometrijske, aritmetičke, harmonijske) ispoljavajući principe samo-sličnosti u prostorno-metričkim progresijama, ali i principe kompleksnosti ili nelinearnosti zasnovane na prekidima simetrije $u$ okviru nemetričkih sistema.

Prvi deo rada objašnjava geometrijske i numeričke relacione figure, ili nizove predstavljajući „osnovne principe lepog i primarne esteske kvalitete svih stvari“ na način na koji ih definišu klasična filozofija, nauka i arhitektura. Ove progresije (njihovi kodovi i algoritmi) zasnovani su na principima regularnosti, najčešće i direktno prostorno reflektovane. Na drugoj strani, složenije relacije i transformacije kao primarni predmet sledećih tematskih jedinica, su transformabilne i nepredvidive, izmičući pravilnoj ekstenzivnoj definiciji. Njihove forme predstavljene su tranzicijama od skalarnih ka ne-metričkim stanjima prikazujući prekide simetrija i apstrakcije, preko složenijih formi dinamičkih modulacija i varijacija materije, zaključno sa nekim od primera digitalne relacione dijagramatike i topologije arhitektonske problematike izvan prostornih ograničenja i prostorne parametarske definicije - sve do dijagrama kao primarnog instrumenta relacionog mišljenja.

KLJUČNE REČI: RELACIONO MIŠLJENJE, DIJAGRAM, KOD, DIJAGRAMATIKA, TOPOLOŠKO MIŠLJENJE, INTENZIVNOSTI DINAMIČKIH SISTEMA, POLJA INFORMACIJA

IZVAN RAZMERE.

UGRADNJA DRUŠTVENE SVAKODNEVICE U ARHITEKTONSKE I UMETNIČKE FORME

\section{Verica Krstić, Milena Kordić}

Kao polazište istraživanja rad problematizuje aktuelizaciju pojma atmosfere u savremenim arhitektonskim i umetničkim istraživanjima u teoriji i praksi. Kroz pojam atmosfere ukazuje se na mogućnosti da arhitektonske i umetničke prakse direktno operacionalizuju svoj interes za probleme svakodnevnog života i kulturu svakodnevice. Arhitektonske i umetničke atmosfere realizuju se u razmeri 1:1, prevazilazeći tako razmere karakteristične za obe discipline pojedinačno. Korisnost primene razmere 1:1 je u potencijalu za odvijanje interdiskurzivne razmene, jer podrazumeva iskustvo fizičkog tela u prostoru i predstavlja medij kroz koji se društvena stvarnost utiskuje u prostor. U ovom radu pokazuje se da je proizvodnja ambijenta mehanizam putem kog ambijentalne umetnosti i arhitektura prevode društvenu svakodnevicu u arhitektonske i umetničke forme u obliku real-size-multimediaworks. 